\title{
ARCHITECTURAL LIGHTING
}

\author{
Vasilenko A., Doctor of Architecture, Professor of the Department Architectural Environment \\ Design Odessa State Academy of Civil Engineering and Architecture \\ e-mail: abvasilenko10@gmail.com,ORCID:0000-0002-8261-3104 \\ +38 (048)-7321801
}

Abstract: Lighting plays a vital role in the way people experience and understand architecture. Whether buildings and structures are lit naturally or artificially, lighting is the medium that allows us to see and appreciate the beauty in the buildings around us. Lighting can bring an emotional value to architecture - it helps create an experience for those who occupy the space. Without lighting, where would architecture be? Would it still have the same impact? Whether it's daylighting or artificial lighting, light draws attention to textures, colors, and forms of a space, helping architecture achieve its true purpose. Vision is the single most important sense through which we enjoy architecture, and lighting enhances the way we perceive architecture even more. To create a successful balance between lighting and architecture, it's important to remember three key aspects of architectural lighting: aesthetic, function and efficiency. Aesthetic is where designers and architects focus on the emotional impact the balance of lighting and architecture will have on occupants. It's where designers determine how they want people to feel when they walk around a space. This aspect is especially important for retail locations; exterior lighting should draw the consumer in, and the interior lighting should awe them as they walk through the doors in addition to showing off product. The second aspect, function, cannot be overlooked. We want the lighting to look a certain way, but we have to also make sure it serves its most important purpose to help us see. Areas should be illuminated so occupants feel safe when navigating a room or entire building. They should be able to see the floor and walls around them, which should create a feeling of reassurance. The final aspect is very important in today's age of green building and sustainability movements. It's one thing to create a breathtaking lighting layout, but it's another to create a breathtaking layout that is also incredibly energy efficient. This can be done by assuring the majority of the light is reaching its target and there is less wasted light. Reducing the amount of wasted light will make the building more efficient. An easy way this can be done is to install LEDs instead of fluorescent lighting. Because of the technology, there is less wasted light with LEDs than fluorescent due to the directional nature of LEDs. Before we get into how light and architecture impact one another, it's important to know the main categories of buildings and what each try to accomplish with lighting. The first group (public buildings) is comprised of sports arenas, libraries, hospitals, etc. These types of buildings are more concerned with providing the right amount of light for tasks and other types of events. Sporting events like football and baseball require the right amount of light so the players on the field can see and so the spectators can see the field. It's also important for when spectators go to and from their seats and navigate the rest of the arena/stadium. It's the same concept with libraries and hospitals. In libraries, occu pants need to have the proper light levels to read, write and find books on shelves, while hospitals need high light levels for doctors and nurses to successfully do their jobs. The second group (official buildings) is comprised of mainly warehouses and office buildings. Their number one concern with lighting is the efficiency. With the large energy consumption of those properties, they can't afford to spend a fortune on lighting and the electricity it consumes. And with green building trends on the rise, it's important to have energy-efficient and sustainable lighting. The third and final group (specialized buildings) is comprised of museums, theaters, casinos, etc. These buildings rely heavily on atmosphere and the experiences they can provide. They are concerned with enhancing the appearance of architectural spaces and elements. When people go to a theater 
to see a play or musical, they are expecting an experience before the show even begins. They want to see a beautiful chandelier welcoming them in the lobby, lavish wall sconces lighting the hallway to their seats, and the area around the stage to be lit to accentuate statues, pillars and other architectural features. To enhance architectural elements and evoke emotions, it's important to understand spatial borders and how to properly light them. To enhance vertical borders for example, light should be directed towards wall surfaces. If there is a wall that is a different texture, or simply one that the occupants should notice more than others, wall washing is a great tool. It will draw attention to the wall and make it appear as its own architectural element instead of a piece of an entire room. This can be used in retail locations to draw more attention to wall displays. Horizontal borders can be emphasized by illuminating the floor and ceiling. By lighting the floor, objects and pedestrian surfaces are lit. This is particularly important in dark spaces such as movie theaters and night clubs. The ambient and accent light levels are so low that not enough light reaches the floor, thus requiring the floor to be illuminated. Executed properly, this can act as task and accent lighting. If light needs to be diffused in the room, lighting the ceiling can be a successful strategy. It helps create a uniformity of light throughout the room and provides proper light levels without the use of direct light on objects. After vertical and horizontal borders have been lit, it's important to not forget about lighting architectural elements. Lighting pillars, archways, textures, etc. can draw attention away from a room as a whole, and force the eye to focus on the illuminated architectural elements. In a room full of colors and architectural elements, it's sometimes difficult to make certain areas stand out. Light can help with this problem by making those elements more obvious. This tactic can be used for interior and exterior lighting applications. The study identifies methodological bases of forming an integrated light facilities complex modern residential architecture. Light reveals the form of the architectural object, creates an image. Architecture becomes a source of artificial illumination using light technology. One of main priorities of the research is scientific direction in the creation of bioclimatic and ecological architecture. The problems of the effective use of the aesthetic potential of natural and artificial light have been considered. The analysis of scientific works has focused on the following issue - in the process of developing of the facade systems of housing building the necessary value of role of functional formation of form by light hasn't been provided. Today in the architectural planning, it is necessary: the introduce in Ukraine European norms, to conform the national normative base the norms of the European standards.

Key words: architectural composition; compositional thinking; light means; residential architecture; methodological principles; natural and artificial lighting.

\title{
АРХІТЕКТУРНЕ ОСВІТЛЕННЯ
}

\author{
Василенко О., док. арх., проф., зав. каф. дизайну архітектурного середовища \\ Одеська державна академія будівництва та архітектури \\ e-mail: abvasilenko10@gmail.com,ORCID:0000-0002-8261-3104 \\ +38 (048)-7321801
}

Анотація: Наукове дослідження визначило методологічні основи формування комплексу світлових засобів в архітектурному проектуванні сучасної житлової архітектури. Важливо, що світло розкриває форму архітектурного об'єкта, створює зображення. Архітектура стає джерелом штучного освітлення 3 використанням світлотехніки. Одним 3 головних пріоритетів роботи $\epsilon$ науково-педагогічний напрямок створення біокліматичної та екологічної архітектури. Проаналізовані проблеми ефективного використання естетичного потенціалу природного та штучного світла. Аналіз наукових робіт виділив основні питання про те, що у процесі проектування фасадних систем житлового будівництва не було надано необхідної цінності ролі функціонального формування форми світлом. Потік природного світла, який має лише напрямок, орієнтується об'ємними формами в рівних умовах 
освітлення. Природне світло направляється на поверхню, яка світиться потоком паралельних променів. Поліпшення проектного завдання потребує визначення параметрів потужності архітектурного світлового середовища, необхідного для оптимізації форм житлового будівництва. Обробка світла та тіні є основним інструментом для роботи 3 іншою формою стародавнього архітектора. Сьогодні в архітектурній освіті при проектуванні необхідно впроваджувати сучасні європейські норми, гармонізувати національну нормативну базу з нормами європейських стандартів.

Ключові слова: архітектурна освіта, архітектурна композиція, композиційне мислення, комплекс світлових засобів, житлова архітектура, методологічні принципи, природне і штучне освітлення.

\section{АРХИТЕКТУРНОЕ ОСВЕЩЕНИЕ}

Василенко А., док. арх., проф., зав. каф дизайна архитектурной среды Одесская государственная академия строительства и архитектуры e-mail: abvasilenko10@gmail.com,ORCID:0000-0002-8261-3104 +38 (048)-7321801

Аннотация: Научное исследование определило методологические основы формирования комплекса световых средств в архитектурном проектировании современной жилой архитектуры. Важно, что свет раскрывает форму архитектурного объекта, создает изображение. Архитектура становится источником искусственного освещения с использованием светотехники. Одним из главных приоритетов работы является научнопедагогическое направление создания биоклиматической и экологической архитектуры. Проанализированы проблемы эффективного использования эстетического потенциала естественного и искусственного света. Анализ научных работ выделил основные вопросы о том, что в процессе проектирования фасадных систем жилищного строительства не было предоставлено необходимой ценности роли функционального формирования формы светом. Поток естественного света, который имеет только направление, ориентируется объемными формами в равных условиях освещения. Естественный свет направляется на поверхность, которая светится потоком параллельных лучей. Улучшение проектного задания требует определения параметров мощности архитектурной световой среды, необходимой для оптимизации форм жилищного строительства. Обработка света и тени является основным инструментом для работы с другой формой древнего архитектора. Сегодня в архитектурном образовании при проектировании необходимо внедрять современные европейские нормы, гармонизировать национальную нормативную базу с нормами европейских стандартов.

Ключевые слова: архитектурное образование, архитектурная композиция, композиционное мышление, комплекс световых средств, жилищная архитектура, методологические принципы, естественное и искусственное освещение.

Formulation of the problem. Relevance. The problems of psychological comfort for life activity of people, the problem of providing high-quality architectural environment, as well as those of effective aesthetic potential of natural and artificial light and innovative light technologies are topical nowadays. Determining the power parameters of the environment, necessary to optimize the form of housing buildings needs to the improved, with European norms being introduced to Ukraine and of national normative base being conformed to the norms of the EU.

The analysis of scientific works enables to distinguish open questions, that lay in the fact that the process of the development of the housing building facade systems not enough attention in given to the role functional and shaping function of light. Actuality of the theme is predefined by 
the necessity to perfect scientifically reasonable practice of forming modern light facilities, which has become pre-condition for the formulation of the aim and task of this research.

In a methodological aspect, the existing research of the predecessors do not summarize all the complex of tasks that must be solved within the framework of forming the complex of light facilities in the architecture of low-rise accommodation. The system vision of the architecture of these buildings in the context of such an important point as ethno cultural identity and the life activity environment.

Among basic research papers in the field of theory of solar radiation, calculations of insolation in architecture, relief treatment of facades of housing building there are the works of such scientists, as: O. Sergejchuk, V. Belikova, S. Vetoshkin, N. Gusev, L. Dashkevich, V.Drozdov, B. Dunaev, D. Lazarev, I. Ckrill, J. Hraska, R. Jonson, R. Kittler, F. Erisman, R. Hopkinson, J. Koso, A. Olgaj, T. Rodgers.

Thus, the practices of forming the complex of light facilities in architecture of housing buildings is in the center attention of important questions of ecology and architecture.

The aims of research is to determine methodological principles of forming the complex of light facilities in architecture of housing building.

The tasks of the research consist that it is necessary: 1. To formulate methodological principles of formation of the complex of light facilities in modern residential architecture during the educational process at the architectural institute. 2. To define progress of typology of housing building trends in the aspect of using the complex of light facilities. 3. To define and systematize the traditional architectural-compositional of shaping means. 4. To analyses chiaroscuro correlations that are the composition means of architectural Shaping. 5. To show the role of the light as a shaping basis of architectural composition.

Objective - Architectural Lighting.

Materials and Methods. Methods of the influence of the research on forming the complex of light facilities in the architectural housing systems are based on Ecosystem deco approach and analyse the light environment that forms interaction of light with architecture.

A general method of investigation of the "light component" of architectural systems is suggested. The methods for assessing the factors influencing the formation of the complex of light facilities are determined. A research methodology and criteria for as sessing the form snapping are proposed.

The study contains an analytical review of the given well-known research methods used in the theory of architecture, research methods and criteria for evaluating the "light component" of architectural systems, as well as the method of research formative and "comfortable function" of light in architecture. The research methodology focuses on aesthetic aspects.

Architectural activity is regarded as an ecological system "man - environment". The ecological system has four components: 1 production sphere (production of technical products);

2 - non-production sphere (service); 3 recreational sphere (special type of activity);

4 communication sphere.

The role of solar energy for each of these components is specific and requires separate case studies. Improved methods for the experimental study of sunlight in the exterior and interior of modern residential buildings, including:

- the method of visual observation of the influence of natural light on architectural form and its emotional-aesthetic perception of a person;

- the method of expert estimations of the conditions of the light environment for productive implementation of home activities, to create the optimum mental attitude and the rest.

The methods suggested take into account the trends of development of modern functional and spatial architectural structures, layouts, typological and compositional characteristics.

light complex In this research next definition of concept is taken for basis complex of light facilities: tis totality of sources of the natural, combined lamplight, that provide insolation, 
sanitary-hygienic norms, comfort and aesthetic light environment, integrated in the systems of engineering constructions with the aim of solving modern architectonically-composition tasks.

As already noted before, with the change of natural illumination the character of illumination of architectural forms changes for a day, but always so, that these forms continue to be perceived with the personal touches peculiar to them. Unlike natural illumination, lamplight creates visual illusions (curvature of form, unclearness, fabulousness) [1].

The stream of natural light that has the only direction puts as if to it by volume oriented forms in the equal terms of illumination. Natural light is usually sent to the surface that is illuminated by the stream of parallel rays, thus, every curvilinear surface in every point meets with him under another corner, in turn, and determines different luminosity in these points (fig. 1,2).

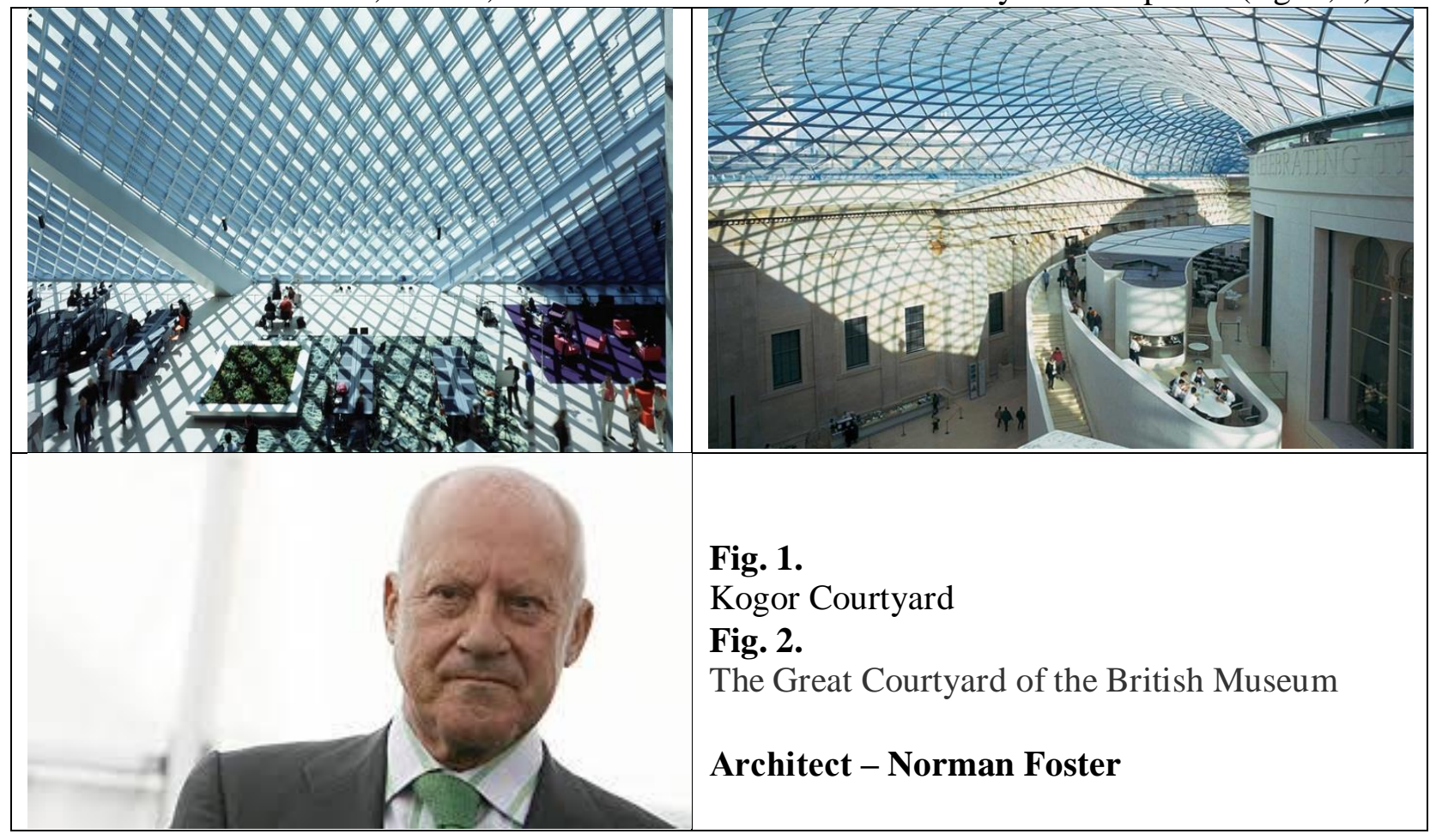

Every plane in all points will meet with the homogeneous stream of rays sent to it strictly under the same corner and, thus, will get the same luminosity all throughout [2].

Therefore, an idea about a plane is bound in our consciousness with the idea about practically unchanging luminosity. An idea about curvilinear surfaces is related to the idea about luminosity appropriately variable of this surface. Significant in size after sizes forms (plane), the sources of artificial light are illuminated by the divergent pinches of light rays sent to them. Thus, a plane cannot get even luminosity in all points, because in its every point is on the different distance from the source of light and other corner with the ray sent to her forms a plane in this point (fig. 3, 4).

A curvilinear surface at the sources of illumination, located on her geometrical wasp or in a geometrical center, appears the friendliest, particularly to even distribution of luminosity on it [3].

Compositional means of architectural lightforming. Studying the issue of detecting architectural form by light, A.S. Sheepanov deems it wise to divide the considered material into three parts (see fig. 5): detecting general, basic architectural form (general forms of ceiling) by light; detecting the plastic, of the details [4].

The visuognosis of the form is determined by distribution of brightness. An ordinary plane can at certain illumination look concave, protuberant or wave. The illusion of undulating curvature of the even surface is by the rhythmic change of into its luminosity in called "bright by waviness". The sources of light influence the degree of "bright waviness" of architectural surfaces. Not 
eliminated is the probability of achieving such an effect also by means of metrical rows of lightpervious architectural constructions [5].
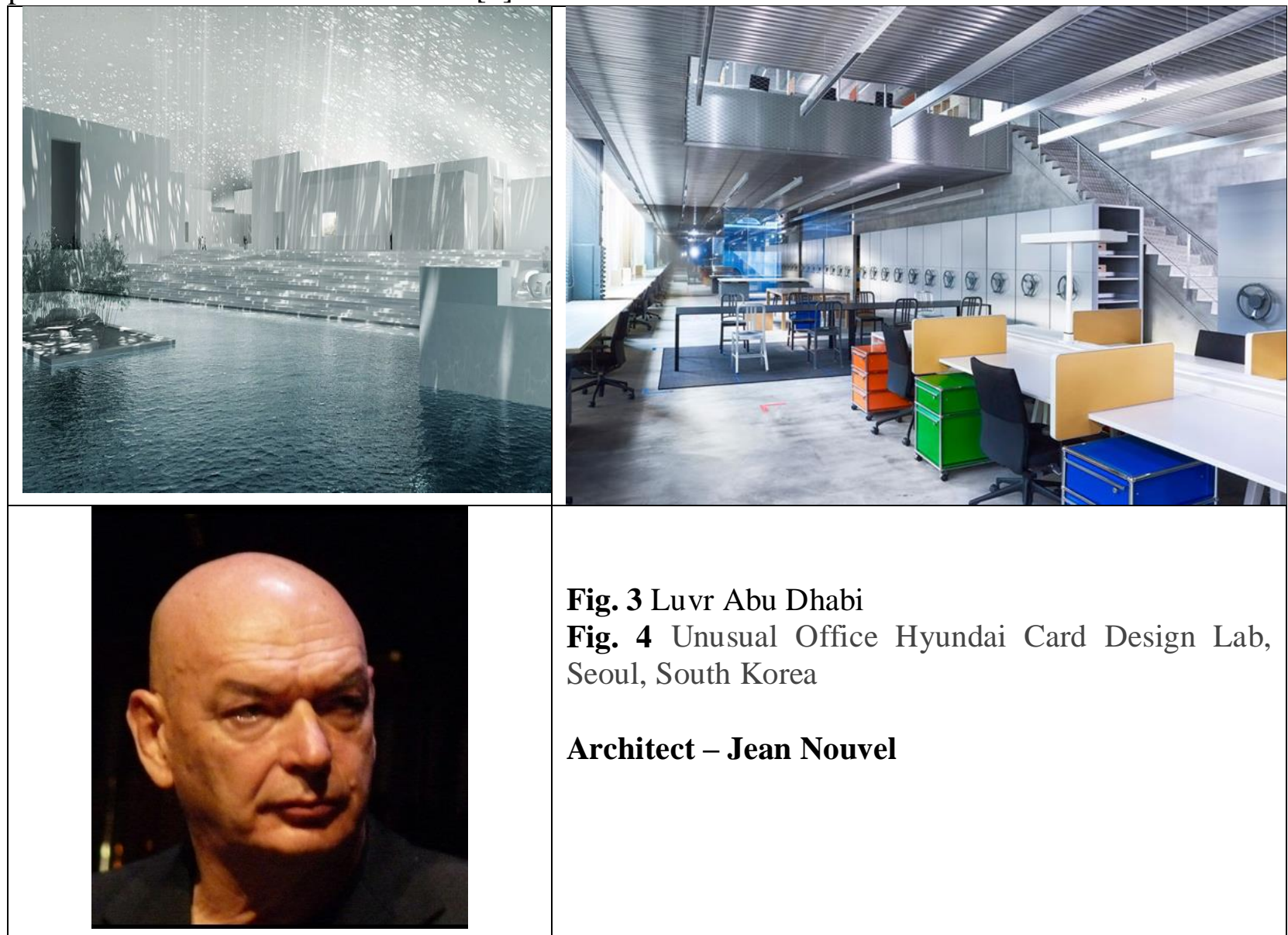

Fig. 3 Luvr Abu Dhabi

Fig. 4 Unusual Office Hyundai Card Design Lab, Seoul, South Korea

Architect - Jean Nouvel

Light forms an artistic image. Light can create different tints of mood. Light can be sullen and mysterious, joyful and soothing, intimate and relaxing, etc. Herein intuition of the designer has a primary value as playing of the chiaroscuro on the emotional coloring of interior (fig. 6).

Light - form shaping basis of the architectural composition. Among the tasks related to the improvement of the quality of light environment, visibility and perception of objects and surfaces are of great importance. Quality of visibility and perception to a great extent is determined not only by the only the parameters of the illumination of building and development of territories but also by the properties of a human eye. Human eye of well-adjusted to the sunbeams, as the light energy sources. Observing the colored surfaces at the change of brightness level within the limits of the corresponding area of photopia, is accompanied by the change of the color feeling (phenomenon of Bezold-Brückk), especially noted at sunny illumination of surfaces of facades and details that got among architects an estimation of being «sunlight destroys a color» (fig. 7).

New concepts "bioarchitecture" and "ecobuilding" come from the architectural culture of the old times, when people lived exceptionally in ecobuildings. For building materials from an environment were used. Building here adapted to the local climate conditions. Bioarchitecture and sunlight mutually influenced each other and coexisted in unity. In modern conditions the main in building methods, remains to enter building in a surrounding landscape and carry out the intention of the customer to take into account local traditions in the use of materials. Since ancient times the basic building materials were natural materials -soil, clay, stone, timber, grass, and reed. In Central Europe the most widespread materials were an adobe brick, rammed soil, wooden ceiling with the reed roof. A roof protruding from every quarter is protected from summer heat and scalding sun. The basic requirement that is applied to all types of ecobuilding: after the completion of the term of life the house is to be applied laid out in a natural environmentor fit for the new use (fig. 8). 


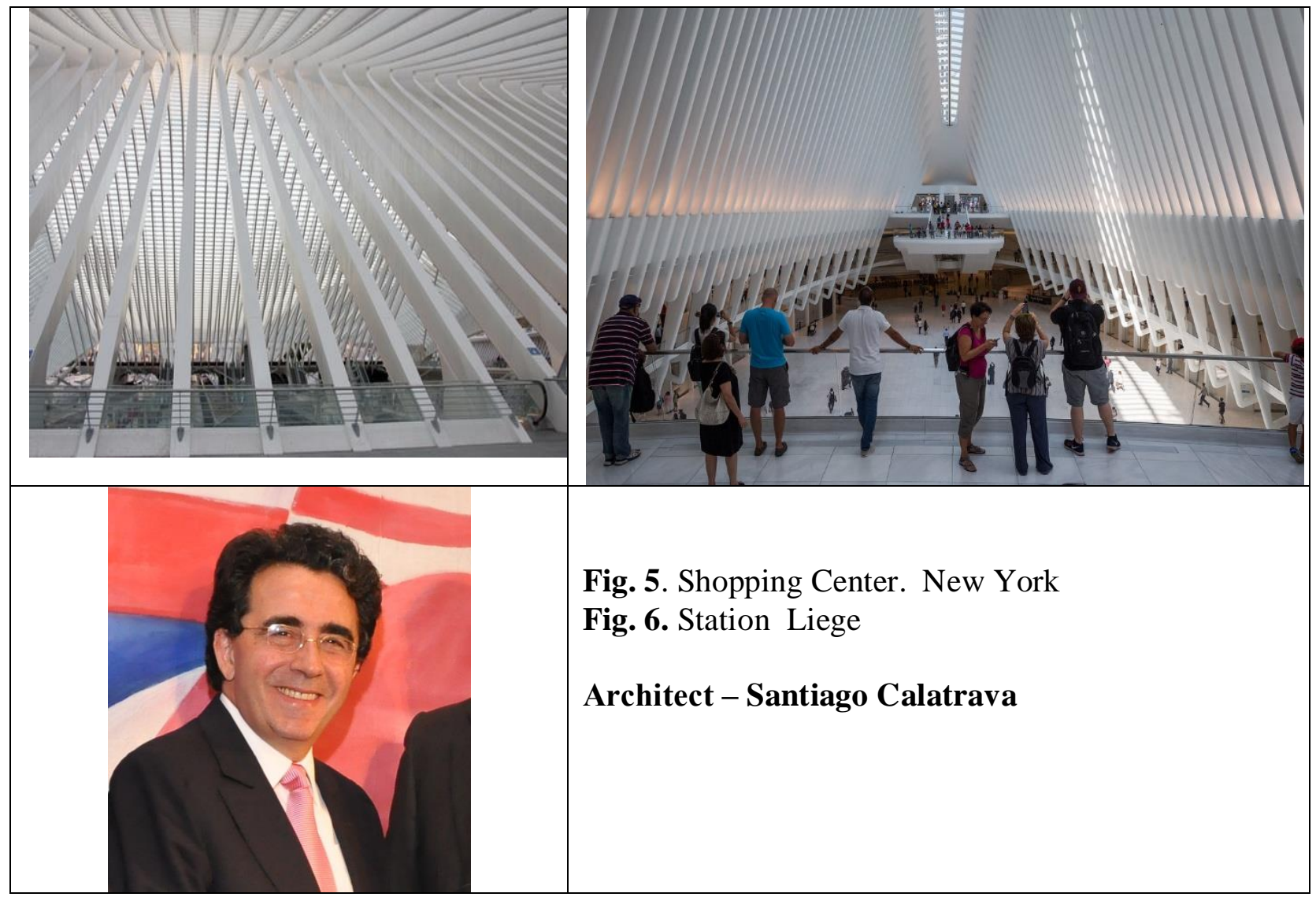

the design and construction of eco-friendly houses, are combined architectural, planning and constructive techniques for improving energy efficiency are combined. With the use of environmentally friendly building materials and structures, such as wall panels of pressed rye straw, stuccoes with clay, we get an increase in the level of environmental friendliness.

Moreover, environmental friendliness is improved in three directions: 1 environmental friendliness and renewability of materials of basic structures (walls and floors); 2 reduction of energy for wall production and installation (compared to ordinary brick - less than 300 times); 3 the cost of construction of $1 \mathrm{~m}^{2}$ of buildings of straw panels (blocks) can be 3 times less compared to traditional structural systems (brick, reinforced concrete flooring) [6-8].

On territories with different climatic terms, with the form of different types of ecobuilding are constructed. On flat, cool territories the most widespread "houses with the form of the hump are popular". On territories with temperate climate, buildings can be more open, on while large glass surfaces that serve as traps for heat. The orientation of the house is also important.

Technological developments in architecture enable to use energy of the Sun multilaterally. Application of active and passive facilities of sunny architecture allows to decrease part of fossil power mediums in exploitation of houses. The advantageous difference of sunny architecture is contained in that the requirement diminished to the possible minimum in energy was satisfied by means of energy of the Sun. The situation of eco-building and environments must be created consciously. While choosing the methods building radiative life-going sourse is always taken into account - Sun. Architects, if a house expresses the inner world of people that live in it, then it becomes the physical "projection" of the spiritual and moral state of maintenance of connections between a man and a house.

For Europeans the period of time, when it is necessary to ward off the Sun by shading, lasts approximately from May to September. On the south side of the house for shading, cultivate leafy plants that will cool him [9]. On east, western and north parties of the house best of all is to plant 
evergreens. In summer, period plants give shade and coolness. Going back to a Sun, leaves are created shade.

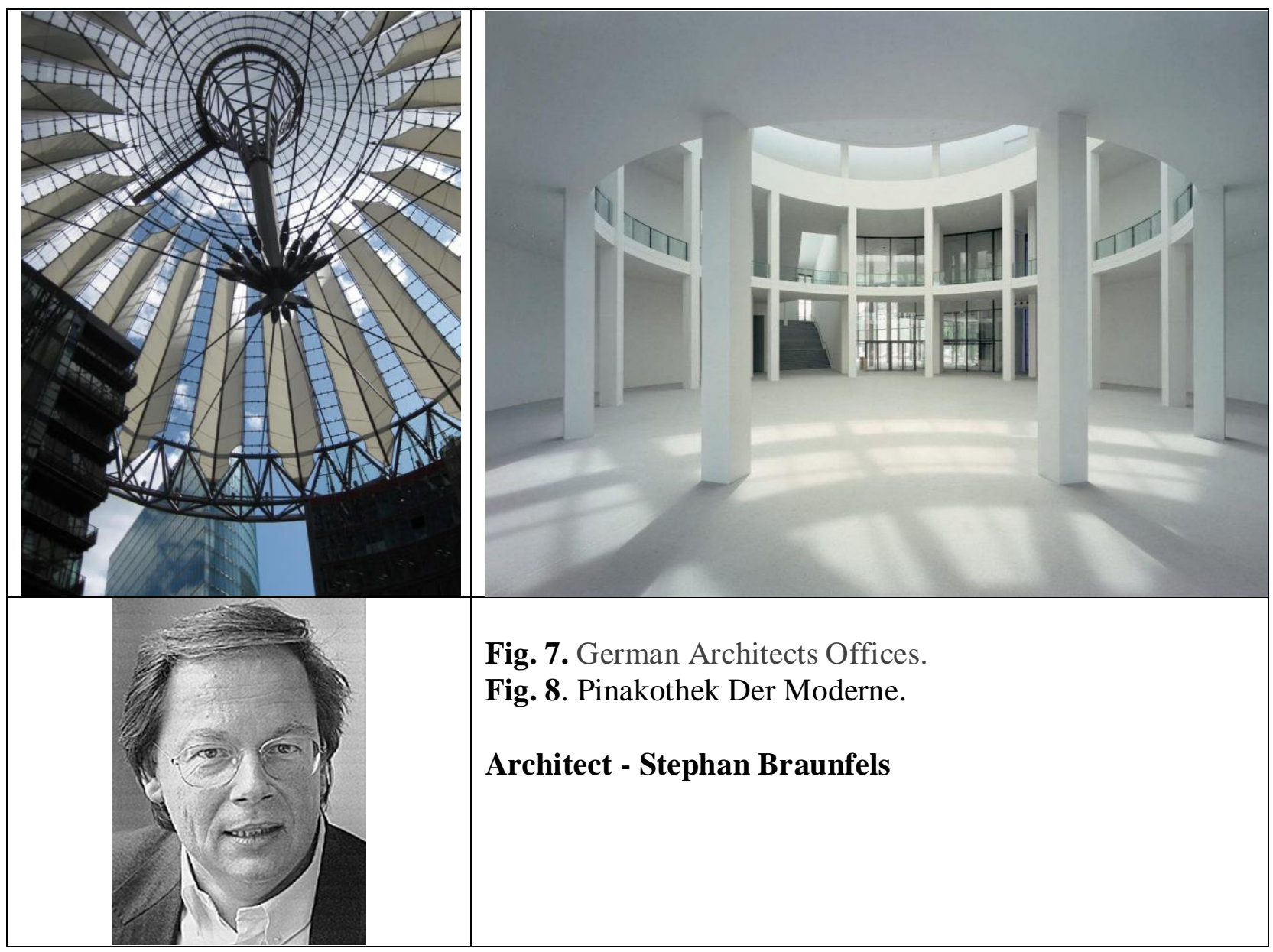

In Europe standards and norms are to planning of house, have obligatory character both for an architect and for those, who will use building. Some positions, that operate in this period in Central Europe in relation to the standards of natural illumination and insolation's following: general norms in relation to a garden, general norms in relation to minimum distances between building, general norms in relation to ventilation of apartments, sizes of apartments, their insolation and natural illumination [10].

After these norms at the estimation of quality of house, a basic factor will be natural light, and by a quality factor is natural insolation. If they provide a wonderful panorama from a window (a kind is from a window), an accommodation already can be subsumed «luxury» [11].

\section{Conclusions}

1. Methodological principles of forming the complex of light facilities of modern norming of architecture: to "subordination of light constituent" to architecture \& plan decisions; "symbiosis of climatological and architectural form"; "introduction of new building technologies"; "use of innovative means of illumination".

2. Light-shadow correlations are the important composition means of architectural shaping that carries out influence on other composition facilities. By means of light, it is possible to define the relief of flat surface (frontal), strengthen then or weaken the feeling of weight or lightness by volume form (long shadows give the impressions of heavy form, short, - vice versa).

3. The role of light is shown as shaping bases of architectural composition. Quality and comfort of architecture depended on ability of the master to use and combine these elements, both in internal and in external space. 


\section{LITERATURE}

1. Ajzenberg Yu. B. Energoeffektivnoe osveshhenie. Problemy i resheniya. / Yu. B. Ajzenberg, O. V. Maloxova // Energosovet.- 2010. -№ 6(11). - S. 20-26.

2. Shhipanov A.S. Osveshhenie v arxitekture interera / A.S. Shhipanov - M.: Gosstrojizdat, 1960. $-116 \mathrm{~s}$.

3. Seppanen O. Trebovaniya k energoeffektivnosti zdanij v stranax ES / O. Seppanen // Energosberezhenie. - 2010. - № 7. - S. 42-51.

4. Koso J. Solnechnyj dom. Estestvennoe osveshhenie v planirovke i stroitelstve / J. Koso / Per. s vengerskogo A. I. Guseva. - M.: ZAO «Izdat. gruppa «Kontent»», 2008. - 174 s.

5. Hraska J. Doba insolacie okien tienenych zastavbou / J. Hraska // Zbornik vedeckych prac Stavebnej fakulty SVST 1985. - Bratislava: Alfa, 1988.

6. Koniuk A. Problemy arkhitekturnoi orhanizatsii ekolohichnoho ta enerhoefektyvnoho zhytla na prykladi ekolohichnoho blokovanoho zhytlovoho budynku v m. Poltava. / Andrii Koniuk, Kateryna Danko // Enerhoefektyvnist v budivnytstvi ta arkhitekturi. - 2018. - N 11. - S. 112119. - Rezhym dostupu: DOI : 10.32347/2310-0516.2018.11.112-119.

7. Budivnytstvo $\mathrm{z}$ solomianykh blokiv. Osnovni etapy zvedennia Ekobudynku $\mathrm{z}$ solomy [Construction of straw blocks. The main stages of erection of EcoBuilt from straw]. URL: gidproekt.com/stroitelstvo-iz-solomennyx-blokov-osnovnye-etapy-vozvedeniya-ekodomoviz-solomy.html (in Ukrainian).

8. Vyrobnytstvo i budivnytstvo karkasnykh budynkiv $\mathrm{z}$ solomianykh panelei [Production and construction of frame houses with straw panels]. URL: eco-bud.com (in Ukrainian).

9. Kittler R. Luminace distribution characteristics of homogeneuns skies / R. Kittler // Light. Res and Technol, vol. 17, № 4, 1985.

10. Vasylenko O. Visual optical effects in architecture / O. Vasylenko, N. Polshchikova, M. Stashenko, V. Zajarko // Problems of Theory and History of Ukrainian Architecture: Collection of Scientific Papers: output.19 / - Odessa: Astroprint, 2019. - 389 s. S. 16 - 24. Rezhym dostupu: DOI: 10:31650/2519-4208-2019-19-16-23.

11. Sergejchuk O.V. Vimogi norm ES - osnova rozroblennya kompleksu normativnix dokumentiv z prirodnogo ta shtuchnogo osvitlennya / O.V. Sergejchuk. // Suchasni problemi texnichnogo regulyuvannya u budivnictvi: zbirnik naukovix prac/ - K.: KNUBA, 2015.

УДК 728.03 doi: 10.31650/2519-4208-2020-20-238-249

\section{СВІТЛОКОЛІРНА ОБ'СКТНО-ПРОСТОРОВА СЕРЕДОВИЩНА СИСТЕМА ТА ЇÏ ПІДСИСТЕМИ У СТРУКТУРІ ЗУПИНОЧНО-ТЕРИТОРІАЛЬНИХ ПРОСТОРІВ}

Товбич В. В., доктор архітектури, професор, завідуючий кафедри інформаційних технологій в архітектурі

Київський національний університет будівництва і архітектури e-mail: tovbych@gmail.com, https://orcid.org/0000-0002-4794-4944

Куліченко Н. В., старший викладач кафедри основ архітектури, Придніпровська державна академія будівництва та архітектури e-mail: n.kulichenko@ukr.net, https:// orcid.org/0000-0002-2080-6488

Кондрацька О. I., аспірантка кафедри інформаційних технологій в архітектурі Київський національний університет будівництва і архітектури e-mail: olga2018cat@gmail.com 